\title{
PENGEMBANGAN INSTRUMEN PENGASUHAN BERBASIS NILAI BUDAYA JAWA
}

\author{
Agnes Indar Etikawati ${ }^{\left.{ }^{*}\right)}$, Juke Roosjati Siregar ${ }^{1}$, Ratna Jatnika ${ }^{1}$, Hanna Widjaja ${ }^{1}$ \\ ${ }^{1}$ Program Doktor Psikologi, Universitas Padjadjaran Bandung, Jawa Barat 45363, Indonesia
}

${ }^{*}$ E-mail: agnes.indar@gmail.com

\begin{abstract}
Abstrak
Konsep pengasuhan tidak dapat lepas dari konteks budaya setempat. Penelitian ini bertujuan untuk mengembangkan instrumen pengukuran pengasuhan untuk populasi keluarga Jawa. Penelitian dilakukan dengan desain exploratory sequential mix method. Diawali dengan tahap eksplorasi konstruk pengasuhan dan dilanjutkan dengan tahap pengujian model pengukuran. Tahap eksplorasi dilakukan dengan menggunakan diskusi kelompok terarah $(F G D)$ dengan melibatkan 50 ibu dan wawancara terhadap 19 orang tua bersuku Jawa yang tinggal di Yogyakarta. Tahap eksplorasi konstruk menghasilkan konsep pengasuhan yang dilandasi tujuh nilai budaya Jawa, yaitu nilai hormat, rukun, kendali perilaku, nrimo (sikap menerima), disiplin, jujur dan tresno (cinta). Konstruk kemudian digeneralisasikan ke dalam butir-butir pernyataan yang dapat dipahami oleh anak-anak. Tahap pengujian model pengukuran melibatkan siswa kelas 5 SD sebanyak 334 anak untuk uji coba pertama dan 175 anak untuk uji coba kedua. Hasil pengujian model pengukuran menunjukkan bahwa konstruk pengasuhan berbasis nilai Jawa dapat dinyatakan valid (dengan $R M E S A=0,063$ dan $S R M R=0,068$ ) dan reliabel (Cronbach's alpha $=0,925)$. Hasil tersebut menunjukkan relevansi nilai-nilai budaya setempat dalam pengembangan pengukuran pengasuhan.
\end{abstract}

Kata kunci: budaya, instrumen, nilai, pengasuhan, suku jawa

\section{Instrument Development of Javanese Valued Based Parenting}

\begin{abstract}
The concept of parenting cannot be separated from the context of the local culture. This study aimed to develop an instrument of parenting for Javanese families. The study was conducted using design of exploratory sequential mix method.The first step was exploration of the construct of Javanese parenting, and the second was the examination of measurement model. The exploration step was conducted using focused group discussion (FGD) involving 50 Javanese mothers and an interview involving 19 Javanese parents who live in Yogyakarta. The result of exploration step showed that the concept of Javanese parenting is built upon seven values, that are; value of respect to elder (hormat), harmony (rukun), self-control (kendali perilaku), acceptance ('nrimo'/sikap menerima), self-discipline (disiplin), honesty (jujur), and love (tresno). Then the construct was generalized into items that can be understood by children. The measurement model examination step involved 334 fifth grade students in first trial and 175 fifth grade students on the second trial. The result of the measurement model examination showed that the Javanese parenting costruct is valid (RMESA $=0.063$; SRMR $=0.068$ ) and reliable (Cronbach's alpha $=0,925$ ). The result indicate the relevance of local cultural values in development of parenting instrument.
\end{abstract}

Keywords: culture, instrument, javanese ethnic, parenting, value

\section{PENDAHULUAN}

Pengasuhan merupakan faktor yang penting dalam kehidupan anak-anak. Melalui pengasuhan, orang tua menjalankan perannya yakni memberikan perawatan, memberikan dukungan emosional, serta melakukan sosialisasi mengenai keterampilan-keterampilan dan nilai-nilai yang perlu dimiliki anak untuk menjadi anggota masyarakat (Grusec, 2002; Maccoby, 1992). Sejumlah penelitian menunjukkan bahwa faktor pengasuhan memiliki pengaruh yang signifikan terhadap per- kembangan dan kesejahteraan anak (Bibi, Chaudhry, Awan, \& Tariq, 2013; Talib, Mohamad \& Mamat, 2011; Xu, 2007).

Pengasuhan memiliki peran yang penting dan sering dijadikan sebagai determinan utama dalam penelitian di bidang ilmu keluarga dan perkembangan anak. Akan tetapi, ruang lingkup pengukuran pengasuhan masih terbatas. Pada umumnya, termasuk di Indonesia, pengasuhan seringkali digambarkan dalam konsep gaya pengasuhan yang dikenalkan oleh Baumrind (1966) dan merupakan konsep yang paling luas 
digunakan dalam studi mengenai pengasuhan dan kaitannya dengan perkembangan anak. Pendekatan Baumrind memuat dimensi kehangatan (warmth) dan kendali (control) dalam menjelaskan beberapa jenis gaya pengasuhan. Dimensi kehangatan mengacu pada sejauh mana orang tua mendukung anak, menghabiskan waktu dan berkomunikasi dengan anak, serta responsif terhadap kebutuhan anak. Kendali mengacu pada sejauh mana orangtua menetapkan dan menegakkan batasan-batasan serta memantau kegiatan anak. Berdasarkan kedua dimensi tersebut, pengasuhan dapat dibedakan menjadi tiga tipe yaitu pengasuhan autoritatif, pengasuhan autoritarian, dan pengasuhan permisif (Power, 2013).

Pengasuhan memiliki lingkup konsep yang luas. Istilah parenting sendiri berasal dari bahasa Latin 'parere' yang berarti to bring forth yang berarti menghasilkan, mengembangkan, atau mendidik. Istilah 'parenting' lebih merujuk pada suatu aktivitas untuk mengembangkan dan mendidik, bukan sekedar siapa yang melakukannya (Clarke-Stewart, 2006). Pengasuhan juga merujuk pada berbagai aktivitas yang dilakukan orang tua untuk menjalankan perannya sebagai orang tua. Peran orang tua yaitu memberikan perawatan dan dukungan emosional serta melakukan sosialisasi mengenai berbagai keterampilan dan nilai-nilai (Grusec, 2002; Maccoby, 1992). Secara umum, pengasuhan mencakup segala aktivitas atau tindakan yang dilakukan orang tua untuk mencapai perkembangan yang diharapkan pada anak-anak.

Begitu luas konsep pengasuhan dapat dipahami dengan beberapa perspektif, di antaranya perspektif mekanistik, perspektif organismik, dan yang paling dikenal adalah perspektif dimensi pola (Kim, 2006). Perspektif mekanistik melihat pengasuhan sebagai proses pembelajaran seperti di laboratorium dengan prinsip-prinsip pengkondisian atau penguatan (Maccoby, 1992). Perspektif mekanistik tercermin dari teori-teori belajar atau teori perilakuan yang mengasumsikan adanya mekanisme $S-R$ (stimulus-respon) (Kim, 2006). Sementara itu, perspektif organismik melihat pengasuhan sebagai interaksi afeksional antara individu (organisme) dan lingkungannya. Teoriteori yang menggunakan perspektif organismik ini adalah teori psikoanalisis dari Freud (Darling \& Steinberg, 1993; Kim, 2006), teori penerimaan-penolakan (acceptance-rejection) dari Rohner (2004), teori attachment dari Ainsworth dan Bowlby (1991). Selanjtnya, perspektif dimensi pola (dimension of pattern) merupakan perspektif yang muncul sebagai upaya mempelajari variasi normal pengasuhan. Perspektif dimensi pola mengkombinasikan antara proses instrumental (control) dan proses afeksional (nurturing), seperti misalnya pola parental warmth (acceptance-rejection) dan parental control (permissiveness-strictness) yang dikembangkan Rohner dan Rohner (1981); kendali (control) dan kehangatan (warmth) yang dikembangkan Baumrind (1966) dan responsiveness dan demandingness (Maccoby \& Martin, 1983).

Sejumlah penelitian di barat, seperti di Amerika (Steinberg, Lamborn, Darling, Mounts, \& Dornbusch, 1994), di Inggris (Shucksmith, Hendry, \& Glendinning, 1995), dan di Finlandia (Aunola, Stattin, \& Nurmi, 2000) menunjukkan bahwa pola asuh otoritatif merupakan pengasuhan yang optimal bagi perkembangan anak. Beberapa penelitian di budaya timur menunjukkan fenomena yang berbeda. Sebagai contoh, orang tua China dipandang lebih otoriter dibandingkan orang tua Amerika, namun demikian anak-anak di kedua negara merasa puas tehadap pengasuhan orang tuanya (Quoss \& Zhao, 1995). Selain itu, pola asuh otoriter justru berhubungan dengan prestasi dan keterlibatan yang tinggi pada remaja Afrika (Deater-Deckard \& Dodge, 1997), remaja Hispanik (Torres-Villa, 1995), dan anakanak dalam keluarga Cina (Chao, 2000). Perbedaan tersebut disebabkan karena praktik pengasuhan di budaya-budaya tersebut memuat pola yang khas yang tidak dapat digambarkan dengan konsep kehangatan dan kendali dari Baumrind (Kim \& Wong, 2002; Ang \& Goh, 2006). Sebagai contoh, indikator dimensi kontrol yang dimaksud oleh Baumrind lebih merupakan kepedulian dan dukungan bagi anak-anak di keluarga Cina (Chao, 1994;2000) dan merupakan proteksi bagi anakanak di keluarga Afrika (Randolph, 1995). Dimensi kehangatan di barat lebih menekankan unsur dukungan otonomi sedangkan di budaya timur lebih pada dukungan instrumental (Campen \& Russell, 2010).

Berdasarkan keterbatasan pendekatan dimensi pola, konsep pengasuhan mulai dikembangkan dalam perspektif kontekstual. Perspektif kontekstual melihat perkembangan individu sebagai proses yang terjadi dalam situasi tertentu dan merupakan hasil interaksi antara individu yang berkembang dengan faktor-faktor budaya, sejarah, dan faktor sosial lainnya (Kim, 2006). Konsep yang dikembangkan dengan perspektif kontekstual memiliki makna yang khusus bagi budaya tertentu dan mungkin tidak bermakna bagi budaya yang lain (Wyer, Chiu \& 
Hong, 2009). Sebagai contoh, dengan berakar pada budaya Confusian dan nilai berprestasi, pengasuhan di Cina dirumuskan dalam konsep pola asuh "chiao shun" dan "guan" yang berarti to train dan to govern/to love. Walaupun secara harafiah berkonotasi dengan dimensi kendali (control) namun kedua dimensi memiliki makna kepedulian atau dukungan dari orang tua (Chao, 1994; 2000).

Konsep pengasuhan dalam perspektif kontekstual dikembangkan dengan berbasis pada keyakinan atau tujuan pengasuhan sesuai budaya setempat. Tujuan pengasuhan memuat berbagai keterampilan atau nilai-nilai yang diharapkan atau dianggap penting dalam suatu budaya. Tujuan pengasuhan merupakan salah satu elemen pengasuhan yang menentukan elemen lainnya, yaitu praktik pengasuhan dan pola asuh (Darling \& Steinberg, 1993). Praktik pengasuhan adalah cara-cara yang dilakukan orang tua untuk mencapai tujuan tertentu, sedangkan pola asuh adalah sikap orang tua terhadap anak yang membentuk iklim emosional di antara orang tua dan anak (Darling \& Steinberg, 1993). Dengan ketiga elemen tersebut, pengasuhan didefinisikan sebagai aktivitas kompleks yang memuat sikap dan tindakan orang tua, yang ditujukan untuk mencapai hasil-hasil perkembangan anak (child outcome) dan menghasilkan suatu ikatan emosional (Darling \& Steinberg, 1993).

Penelitian ini akan memaparkan proses pengembangan instrumen pengasuhan dalam budaya Jawa. Suku Jawa merupakan kelompok suku terbesar di Indonesia dengan jumlah mencapai 41 persen dari total populasi di Indonesia (BPS, 2011). Suku Jawa dikenal memiliki prinsip hidup hormat dan rukun, yang dimaksudkan untuk menjaga keselarasan atau harmoni sosial. Prinsip hormat adalah prinsip untuk berinteraksi sosial sesuai tatanan sosial hierarkis, dan prinsip rukun adalah prinsip untuk menghindari konflik dan mempertahankan keselarasan relasi. Dalam keluarga-keluarga Jawa tradisional, seorang anak diasuh agar menjadi "njawani" yang artinya dapat menempatkan diri sesuai kedudukannya dan pandai mengendalikan diri (Geertz, 1983; Mulder, 1983; Suseno, 1984). Orang Jawa juga mengembangkan sikap "sepi ing pamrih, rame ing gawe" yang berarti kerelaan untuk melepaskan kepentingan-kepentingannya sendiri dan menjalankan tugas atau kewajibannya untuk kepentingan dan kemajuan masyarakat (Suseno, 1984), serta kejujuran yang lebih dikaitkan dengan perilaku menepati janji dan bersikap adil (Suseno, 1984). Sebagai penyeimbang terhadap berbagai ajaran berperilaku, anak-anak keluarga Jawa mendapatkan cinta yang tanpa syarat terutama dari ibu (Geertz, 1983).

Konsep pengasuhan yang dikembangkan dalam perspektif kontekstual berbasis pada tujuan pengasuhan atau dilandasi oleh nilainilai budaya setempat. Pengasuhan dalam budaya Jawa dapat disebut juga dengan pengasuhan berbasis nilai-nilai budaya Jawa, yang selanjutnya akan disebut sebagai pengasuhan BNJ. Dengan pendekatan kontekstual, pengembangan alat ukur pengasuhan dalam penelitian ini dilakukan secara induktif yaitu diawali dengan eksplorasi konstruk pengasuhan BNJ. Pengukuran pengasuhan pada umumnya dikembangkan secara deduktif atau mengacu pada literatur terdahulu, seperti pengukuran pengasuhan yang pernah dikembangkan di Cina (Chao, 1994); di Vietnam (Nguyen \& Wiliams,1989), untuk imigran Asia yang tinggal di Amerika (Phinney, Ong, \& Maden, 2000) dan di Jawa sendiri (Idrus, 2005). Hipotesis dalam penelitian ini adalah bahwa konstruk atau model pengukuran pengasuhan BNJ yang diperoleh secara induktif melalui studi eksploratif akan sesuai (fit).

\section{METODE}

Penelitian ini dilakukan dengan desain exploratory sequential mix method. Mix Method itu sendiri merupakan merupakan pendekatan penelitian yang mengombinasikan penelitian kualitatif dan penelitian kuantitatif. Lebih lanjut, pendekatan ini melibatkan beberapa asumsi filosofis, aplikasi pendekatan kuantitatif dan kualitatif, serta pencampuran kedua pendekatan tersebut dalam satu penelitian. Penelitian ini memiliki sifat yang lebih kompleks dari sekadar mengumpulkan dan menganalisis dua jenis data karena melibatkan juga fungsi dari dua pendekatan secara kolektif sehingga kekuatan penelitian ini secara keseluruhan lebih besar jika dibandingkan dengan penelitian kuantitatif atau penelitian kualitatif (Creswell, 2014). Penelitian ini diawali dengan tahap eksplorasi konstruk alat ukur yang dilanjutkan dengan tahap pengujian model pengukuran yang dilakukan dengan pendekatan kuantitatif (survei). Populasi dalam penelitian ini adalah keluarga Jawa yang tinggal di Provinsi Daerah Istimewa Yogyakarta (DIY). Tahap ekslporasi konstruk melibatkan 19 orang tua yang diperoleh dengan purposive sampling, sedangkan tahap pengujian model pengukuran melibatkan 509 anak yang diperoleh dengan stratified random sampling. 
Langkah-langkah pengembangan instrumen pengasuhan BNJ mengacu pada saran ahli (Hinkin, Tracey, \& Enz, 1998), yang meliputi penyusunan pernyataan/pertanyaan, pemeriksaan isi alat ukur, pengumpulan data uji coba, dan pemeriksaan properti psikometrik. Penyusunan pernyataan/pertanyaan dalam studi kali ini dilakukan secara induktif. Diperlukan studi eksploratif terlebih dahulu untuk mendapatkan konsep pengasuhan BNJ. Dengan tetap mempertimbangkan langkahlangkah pengembangan skala di atas, maka secara lebih sederhana pengembangan instrumen pengasuhan BNJ dapat dibagi menjadi dua tahap yaitu tahap eksplorasi kualitatif untuk mendapatkan konstruk pengasuhan dan tahap pengujian model pengukuran.

\section{Tahap Eksplorasi Konstruk}

Konstruk pengasuhan BNJ diperoleh dari eksplorasi pada orang tua. Para responden dipilih berdasarkan beberapa kriteria, yaitu: 1) bersuku Jawa, 2) memiliki anak yang bersekolah di sekolah dasar, 3) menggunakan bahasa Jawa sebagai salah satu bahasa percakapan sehari-hari, dan 4) mempraktikkan tata krama Jawa dalam relasi sosial sehari-hari. Responden diperoleh melalui informan yang dapat memastikan terpenuhinya kriteria. Responden $F G D$ berjumlah 50 ibu yang merupakan anggota atau kader PKK dan terbagi dalam tujuh kelompok FGD; tiga kelompok di Kota Yogyakarta dan 4 kelompok di Kabupaten Sleman, Bantul, Kulon Progo, dan Gunungkidul. Responden wawancara adalah 19 orang tua yang berbeda dari responden FGD, meliputi 8 pasang suami istri dan 3 orang ibu yang tinggal di kota Yogyakarta, Kabupaten Sleman, dan Kabupaten Bantul.

Pengumpulan data pada tahap konstruk pernyataan/pertanyaan dilakukan dengan Focused Group Discission (FGD) dan wawancara karena kedua metode memiliki kelebihan yang dapat saling melengkapi. Data kualitatif yang dikumpulkan dalam FGD dan wawancara meliputi tujuan pengasuhan yang menyangkut pengembangan nilai-nilai budaya Jawa pada anak serta alasan dan cara-cara yang dilakukan orang tua untuk mencapai tujuan tersebut. Tujuan dan cara pengasuhan merupakan elemen yang diperlukan untuk merumuskan konsep pengasuhan (Darling \& Steinberg, 1993).

Sebagian besar langkah-langkah FGD dan wawancara mengacu pada penjelasan Subramony, Lindsay, Middlebrook, dan Fosse
(2002) yaitu meliputi tahap pembuka, pertanyaan pendahuluan, pertanyaan kunci, dan penutup. Pertanyaan pendahuluan ditujukan untuk mengarahkan partisipan pada topik FGD atau wawancara dan dalam hal ini moderator menanyakan apakah keluargakeluarga Jawa saat ini masih mengajarkan nilai-nilai budaya Jawa kepada anak. Pertanyaan kunci menghasilkan jawabanjawaban yang menjadi data utama analisis, yaitu meliputi nilai atau hal baik dalam budaya Jawa yang dianggap penting dan relevan untuk dikembangkan pada anak di masa sekarang; alasan nilai tersebut dinilai penting untuk dimiliki anak; dan cara mengajarkan nilai yang disebutkan. Dalam FGD, moderator mendorong peserta untuk memberikan pendapat, memberikan umpan balik kepada pendapat peserta lain, dan membuat kesepakatan bersama jika terdapat pendapat yang berlawanan. FGD dilakukan satu kali untuk setiap kelompok dan berlangsung selama kurang lebih 2 jam.

Data FGD dan wawancara diolah dengan analisis tematik, yang meliputi pengkodean awal dilanjutkan dengan identifikasi dan penamaan tema-tema (Braun \& Clarke, 2006). Penamaan tema-tema mengacu pada literatur terdahulu mengenai praktik pengasuhan dalam keluarga Jawa dan dimungkinkan adanya penamaan tema atau kategori yang baru sebagai temuan dari tahap eksplorasi.

\section{Tahap Pengujian Model Pengukuran}

Konstruk pengasuhan BNJ yang diperoleh dari responden orang tua dikembangkan menjadi alat ukur yang dapat dikerjakan oleh anakanak. Untuk itu diperlukan responden anakanak untuk tahap pengujian model pengukuran. Responden untuk pengujian model pengukuran diperoleh dengan teknik cluster sampling dan teknik stratified random sampling, dalam hal ini unit cluster adalah sekolah (kelas lima) yang dipilih secara acak mewakili wilayah kota dan empat kabupaten di Provinsi DIY. Responden dalam uji coba pertama berjumlah 334 siswa dari 10 SD dan uji coba kedua berjumlah 175 siswa dari enam SD di DIY. Uji coba kedua perlu dilakukan karena adanya perbaikan sejumlah pernyataan/pertanyaan. Responden yang disertakan dalam analisis diseleksi terlebih dahulu dengan kriteria memiliki orang tua yang keduanya bersuku Jawa dan masih menggunakan bahasa Jawa sebagai salah satu bahasa percakapan sehari-hari di rumah.

Pengujian model pengukuran pengasuhan BNJ dilakukan dengan mengacu pada proses 
pengembangan skala yang dikemukakan oleh Hinkin, Tracey, dan Enz (1997). Proses pengembangan skala diawali dengan penyusunan pernyataan dan pemeriksaan isi pernyataan oleh para ahli (expert judgmet). Berikut penjelasan untuk setiap langkah pengembangan skala.

Pertama, aspek-aspek pengasuhan yang dihasilkan dari studi eksploratif diturunkan ke dalam pernyataan-pernyataan. Setiap pernyataan hanya memuat satu isu, tidak memuat dua atau lebih ide (double barreled questions). Pernyataan mengenai suatu tindakan orang tua atau kegiatan yang melibatkan anak, dirumuskan secara sederhana dan konkret. Format skala jawaban pada instrumen berupa skala Likert dengan tipe pilihan frekuensi, meliputi tidak pernah, kadangkadang, sering dan selalu yang diberikan skor 1 hingga 4. Ke-dua, pernyataan-pernyataan diperiksa oleh ahli yang relevan (expert judgment). Ahli berjumlah tujuh orang, meliputi lima doktor di bidang psikologi perkembangan, satu doktor psikologi sosial yang meneliti tentang nilai-nilai budaya Jawa, dan satu ahli di bidang psikometri. Dua diantara ahli psikologi perkembangan merupakan peneliti transmisi nilai Jawa dan yang lain adalah praktisi program sosialisasi pengasuhan berbasis tradisi Jawa. Tujuan dari expert judgment terdiri dari dua hal, yaitu mendapat penilaian mengenai kategorisasi aspek-aspek pengasuhan dan penilaian mengenai rumusan pernyataan-pernyataan, apakah nantinya pernyataan-pernyataan dapat dipahami oleh responden (anak) dan tidak menimbulkan kerancuan (bias) pemahaman. Ke-tiga, setelah pernyataan-pernyataan diperbaiki, dilakukan pre-test alat ukur pada lima anak siswa kelas lima SD untuk memastikan bahwa pernyataanpernyataan dapat dipahami dan sesuai dengan maksud pengukuran. Ke-empat, skala diadministrasikan pada sejumlah responden anak untuk memperoleh data yang akan dianalisis secara statistik. Agar dapat dilakukan CFA (Conformatory Factor Analysis), jumlah responden (sample size) yang disarankan adalah minimal 100 subjek (Hinkin, Tracey, \& Enz, 1997). Ke-lima, dilakukan seleksi terhadap pernyataan-pernyataan berdasarkan nilai korelasi pernyataan-total (rix), nilai muatan (loading factor), dan bersama pernyataan lain menghasilkan model pengukuran yang fit untuk dimensinya. Ke-enam, seluruh pernyataan yang telah terpilih dianalisis menggunakan CFA untuk mendapatkan informasi mengenai validitas konstruk dan penghitungan nilai Cronbach's alpha untuk mendapatkan informasi mengenai reliabilitas skala.
Analisis data dilakukan dalam beberapa tahapan. Pertama untuk memilih pernyataan (seleksi pernyataan) dan kedua untuk mendapatkan informasi mengenai validitas dan reliabilitas skala (properti psikometri skala). Pernyataan-pernyataan diseleksi berdasarkan nilai corected item-total correlation (rix) yaitu di atas 0,3 atau setidaknya 0,25 (Field, 2009); nilai muatan (factor loading) yang idealnya sebesar 0,7 atau minimal 0,3 (Kline, 2011); dan pernyataan lain dalam aspek yang sama yang menghasilkan model pengukuran yang fit untuk dimensi atau aspeknya. Menurut $\mathrm{Hu}$ dan Bentler (1999), kriteria Godness of Fit (GOF) yang wajib untuk dipertimbangkan adalah nilai $R M S E A$ dan SRMR (yaitu $\leq 0,08$ ) yang menunjukkan besarnya perbedaan antara model teoretis yang diajukan dan data empirik.

Informasi mengenai kesesuaian (fit) model pengukuran tiap aspek dan nilai muatan pernyataan diperoleh dengan Conformatory Factor Analysis (CFA). CFA dilakukan dengan bantuan program AMOS. Jika model pengukuran tidak memenuhi kriteria, diperlukan modifikasi model dengan melihat informasi dari Modification Indicies (MI). Informasi dari MI menunjukkan bahwa terdapat dimensi-dimensi atau pernyataan-pernyataan yang berkorelasi tinggi yang dapat disebabkan karena kemiripan pola respon atau kemiripan isi pernyataan. Modifikasi yang diperlukan biasanya adalah mengganti atau memperbaiki pernyataan. Dalam menindaklanjuti informasi dari $M I$ tetap harus berpegang pada konsep teoretis. Dengan model pengukuran yang telah dinyatakan fit, selanjutnya dilakukan penghitungan koefisien Cronbach's alpha untuk mendapatkan informasi mengenai reliabilitas skala.

\section{HASIL}

\section{Hasil Eksplorasi Konstruk}

Proses pengkodean menghasilkan bahwa ada tujuh kategori nilai yang menjadi tujuan pengasuhan dalam keluarga Jawa. Tujuh kategori nilai tersebut, yaitu hormat, rukun, kendali perilaku, nrimo (sikap menerima), disiplin, jujur dan tresno (cinta). Lebih lanjut, jika ditinjau dari alasan maupun cara yang dilakukan orang tua untuk menanamkan ketujuh nilai-nilai tersebut, ditemukan pandangan atau falsafah budaya Jawa yang menjadi landasan diterapkannya nilai-nilai tersebut. Tabel 1 menunjukkan bahwa hasil analisis tematik yang meliputi kategori nilai, subkategori, cara pengasuhan, dan falsafah yang melandasi nilai yang menjadi tujuan pengasuhan pada budaya jawa. 
Tabel 1 Konstruk pengasuhan Berbasis Nilai Jawa (BNJ)

\begin{tabular}{|c|c|c|c|c|}
\hline$\frac{\text { Kategori }}{\text { (Nilai) }}$ & Definisi & $\frac{\text { Sub Kategori }}{\text { (Indikator) }}$ & Cara Pengasuhan & Falsafah \\
\hline \multirow[t]{8}{*}{ Hormat } & \multirow{8}{*}{$\begin{array}{l}\text { Cara-cara } \\
\text { yang dilakukan } \\
\text { orang tua agar } \\
\text { anak mampu } \\
\text { menunjukkan } \\
\text { rasa hormat } \\
\text { pada orang } \\
\text { yang lebih tua. }\end{array}$} & \multirow[t]{3}{*}{$\begin{array}{l}\text { Menanamkan } \\
\text { rasa sungkan } \\
\text { pada orang } \\
\text { yang lebih tua }\end{array}$} & $\begin{array}{l}\text { Memberikan pengertian tentang } \\
\text { kedudukan anak dan orang lain, } \\
\text { bahwa orang yang lebih tua harus } \\
\text { dihormati. }\end{array}$ & \multirow{8}{*}{$\begin{array}{l}\text { Orang yang lebih } \\
\text { tua mempunyai } \\
\text { kedudukan yang } \\
\text { tinggi sehingga } \\
\text { anak harus dapat } \\
\text { menunjukkan rasa } \\
\text { hormat pada orang } \\
\text { yang lebih tua. }\end{array}$} \\
\hline & & & $\begin{array}{l}\text { Mengingatkan anak walaupun } \\
\text { seperti teman tetapi tidak boleh } \\
\text { seenaknya terhadap orang tua. }\end{array}$ & \\
\hline & & & $\begin{array}{l}\text { Mengajarkan sikap tubuh hormat di } \\
\text { depan orang yang lebih tua }\end{array}$ & \\
\hline & & \multirow{2}{*}{$\begin{array}{l}\text { Mengajarkan } \\
\text { bahasa Jawa } \\
\text { halus }\end{array}$} & Mengajarkan bahasa Jawa halus & \\
\hline & & & $\begin{array}{l}\text { Membetulkan istilah yang masih } \\
\text { kasar }\end{array}$ & \\
\hline & & \multirow[t]{3}{*}{$\begin{array}{l}\text { Membiasakan } \\
\text { perilaku tata } \\
\text { krama }\end{array}$} & $\begin{array}{l}\text { Membiasakan menyapa atau } \\
\text { memberi salam lebih dulu saat } \\
\text { bertemu orang yang lebih tua }\end{array}$ & \\
\hline & & & $\begin{array}{l}\text { Membiasakan anak mengucapkan } \\
\text { permisi ("ndherek langkung") atau } \\
\text { sedikit membungkuk saat berjaan } \\
\text { di depan orang yang lebih tua }\end{array}$ & \\
\hline & & & $\begin{array}{l}\text { Mengajarkan cara merespon orang } \\
\text { yang lebih tua ("dalem", "inggih") }\end{array}$ & \\
\hline \multirow[t]{8}{*}{ Rukun } & \multirow{8}{*}{$\begin{array}{l}\text { Cara-cara } \\
\text { yang } \\
\text { digunakan } \\
\text { orang tua agar } \\
\text { anak mampu } \\
\text { menghindari } \\
\text { konflik dan } \\
\text { menjalin } \\
\text { hubungan baik } \\
\text { dengan orang } \\
\text { lain di } \\
\text { sekitarnya }\end{array}$} & \multirow{3}{*}{$\begin{array}{l}\text { Mengajarkan } \\
\text { pada anak } \\
\text { untuk } \\
\text { menghindari } \\
\text { konflik }\end{array}$} & Mendorong anak untuk bersabar & \multirow{8}{*}{$\begin{array}{l}\text { Manusia harus } \\
\text { dapat hidup selaras } \\
\text { dengan orang lain } \\
\text { sehingga harus } \\
\text { dapat } \\
\text { memperlakukan } \\
\text { orang lain sama } \\
\text { dengan } \\
\text { memperlakukan diri } \\
\text { sendiri dan selalu } \\
\text { berusaha } \\
\text { menghindari konflik }\end{array}$} \\
\hline & & & $\begin{array}{l}\text { Meminta anak untuk mengalah } \\
\text { atau tidak memperbesar masalah }\end{array}$ & \\
\hline & & & $\begin{array}{l}\text { Menasehati anak agar menghargai } \\
\text { perbedaan }\end{array}$ & \\
\hline & & \multirow{3}{*}{$\begin{array}{l}\text { Mempertajam } \\
\text { kepekaan pada } \\
\text { keadaan orang } \\
\text { lain ("tepo } \\
\text { seliro") }\end{array}$} & $\begin{array}{l}\text { Menunjukkan orang lain yang } \\
\text { sedang mengalami kesulitan }\end{array}$ & \\
\hline & & & $\begin{array}{l}\text { Meminta anak untuk membantu } \\
\text { tetangga membutuhkan }\end{array}$ & \\
\hline & & & Membiasakan anak untuk berbagi & \\
\hline & & \multirow{2}{*}{$\begin{array}{l}\text { Mendorong } \\
\text { anak untuk } \\
\text { berinteraksi } \\
\text { dengan orang } \\
\text { lain "srawung" }\end{array}$} & $\begin{array}{l}\text { Membiasakan anak untuk } \\
\text { menggunakan sapaan } \\
\text { kekeluargaan }\end{array}$ & \\
\hline & & & $\begin{array}{l}\text { Mengajak anak untuk bergotong } \\
\text { royong, Mendorong anak mengikuti } \\
\text { kegiatan di lingkungan }\end{array}$ & \\
\hline \multirow[t]{6}{*}{$\begin{array}{l}\text { Kendali } \\
\text { perilaku }\end{array}$} & \multirow{6}{*}{$\begin{array}{l}\text { Cara-cara } \\
\text { yang } \\
\text { digunakan } \\
\text { orang tua agar } \\
\text { anak mampu } \\
\text { mengendalika } \\
\text { n diri } \\
\text { sedemikian } \\
\text { rupa sehingga } \\
\text { perilakunya } \\
\text { tidak } \\
\text { mengganggu } \\
\text { ketenangan } \\
\text { lingkungan }\end{array}$} & \multirow{3}{*}{$\begin{array}{l}\text { Mengajarkan } \\
\text { kepantasan } \\
\text { perilaku }\end{array}$} & $\begin{array}{l}\text { Mengingatkan agar duduk dengan } \\
\text { cara sopan }\end{array}$ & \multirow{6}{*}{$\begin{array}{l}\text { Manusia } \\
\text { semestinya } \\
\text { memiliki kepekaan } \\
\text { dan turut menjaga } \\
\text { ketenangan } \\
\text { lingkungan } \\
\text { sekitarnya. Oleh } \\
\text { karena itu, harus } \\
\text { selalu berusaha } \\
\text { untuk berhati-hati } \\
\text { dalam berperilaku } \\
\text { agar tidak } \\
\text { mengganggu } \\
\text { ketenangan } \\
\text { lingkungan }\end{array}$} \\
\hline & & & $\begin{array}{l}\text { Mengingatkan agar makan dengan } \\
\text { cara yang pantas }\end{array}$ & \\
\hline & & & $\begin{array}{l}\text { Memberitahu mana perilaku yang } \\
\text { "ilok" (pantas) atau "ora ilok" (tidak } \\
\text { pantas) }\end{array}$ & \\
\hline & & \multirow{3}{*}{$\begin{array}{l}\text { Membiasakan } \\
\text { kehalusan } \\
\text { dalam } \\
\text { berperilaku }\end{array}$} & $\begin{array}{l}\text { Memberi contoh untuk berbicara } \\
\text { dengan pelan/ halus }\end{array}$ & \\
\hline & & & $\begin{array}{l}\text { Menegur jika anak bicara keras, } \\
\text { teriak-teriak atau "ceplas-ceplos" }\end{array}$ & \\
\hline & & & $\begin{array}{l}\text { Mengingatkan anak menutup pintu } \\
\text { atau meletakkan barang dengan } \\
\text { pelan }\end{array}$ & \\
\hline
\end{tabular}


(Lanjutan) Tabel 1 Konstruk pengasuhan Berbasis Nilai Jawa (BNJ)

\begin{tabular}{|c|c|c|c|c|}
\hline$\frac{\text { Kategori }}{\text { (Nilai) }}$ & Definisi & $\frac{\text { Sub Kategori }}{\text { (Indikator) }}$ & Cara Pengasuhan & Falsafah \\
\hline \multirow[t]{6}{*}{$\begin{array}{l}\text { Nrimo } \\
\text { (sikap } \\
\text { menerima) }\end{array}$} & \multirow{6}{*}{$\begin{array}{l}\text { Cara-cara } \\
\text { yang } \\
\text { digunakan } \\
\text { orang tua agar } \\
\text { anak memiliki } \\
\text { sikap } \\
\text { menerima } \\
\text { (tidak protes) } \\
\text { dan tetap } \\
\text { beraktifitas } \\
\text { dalam } \\
\text { keadaaan } \\
\text { apapun }\end{array}$} & \multirow{3}{*}{$\begin{array}{l}\text { Mengajarkan } \\
\text { sikap } \\
\text { menerima } \\
\text { (tidak protes) } \\
\text { pada apa yang } \\
\text { diberikan } \\
\text { Tuhan }\end{array}$} & $\begin{array}{l}\text { Memberikan pengertian bahwa } \\
\text { tidak semua keinginan harus } \\
\text { terpenuhi }\end{array}$ & \multirow{6}{*}{$\begin{array}{l}\text { Manusia semestiya } \\
\text { dapat } \\
\text { mengendalikan } \\
\text { keinginan- } \\
\text { keinginan } \\
\text { pribadinya, oleh } \\
\text { karena itu ia selalu } \\
\text { bersikap menerima } \\
\text { dan tetap menjalani } \\
\text { kehidupan dalam } \\
\text { keadaan apapun }\end{array}$} \\
\hline & & & $\begin{array}{l}\text { Menasehati anak untuk menerima } \\
\text { apa yang dimiliki dalam keluarga } \\
\text { (misal menikmati makanan yang } \\
\text { ada) }\end{array}$ & \\
\hline & & & $\begin{array}{l}\text { Mengingatkan anak untuk tidak } \\
\text { banyak menuntut dan berbuat } \\
\text { "neko-neko" (macam-macam) }\end{array}$ & \\
\hline & & $\begin{array}{l}\text { Mengajarkan } \\
\text { anak bersyukur }\end{array}$ & $\begin{array}{l}\text { Membiasakan anak untuk } \\
\text { bersyukur }\end{array}$ & \\
\hline & & $\begin{array}{l}\text { Mendorong } \\
\text { anak untuk } \\
\text { tetap }\end{array}$ & $\begin{array}{l}\text { Menasehati anak untuk menjalani } \\
\text { keadaan apapun dengan hati } \\
\text { senang }\end{array}$ & \\
\hline & & $\begin{array}{l}\text { berkegiatan } \\
\text { dalam keadaan } \\
\text { apapun }\end{array}$ & $\begin{array}{l}\text { Menciptakan suasana gembira di } \\
\text { dalam rumah }\end{array}$ & \\
\hline \multirow[t]{6}{*}{ Disiplin } & \multirow{6}{*}{$\begin{array}{l}\text { Cara-cara } \\
\text { yang } \\
\text { digunakan } \\
\text { orang tua agar } \\
\text { anak dapat } \\
\text { mengarahkan } \\
\text { dirinya dalam } \\
\text { menjalankan } \\
\text { tugas dan } \\
\text { kegiatannya } \\
\text { sehari-hari. }\end{array}$} & $\begin{array}{l}\text { Mendorong } \\
\text { anak untuk }\end{array}$ & $\begin{array}{l}\text { Memberikan anak tanggung jawab } \\
\text { mengerjakan pekerjaaan rumah }\end{array}$ & \multirow{6}{*}{$\begin{array}{l}\text { Manusia } \\
\text { semestinya dapat } \\
\text { mengarahkan } \\
\text { dirinya dan } \\
\text { berusaha } \\
\text { menyelesaikan } \\
\text { tugas dan } \\
\text { kewajibannya }\end{array}$} \\
\hline & & $\begin{array}{l}\text { menjalankan } \\
\text { tugasnya }\end{array}$ & $\begin{array}{l}\text { Mendorong anak menyelesaikan } \\
\text { tugas sekolahnya }\end{array}$ & \\
\hline & & $\begin{array}{l}\text { Mendorong } \\
\text { anak mengatur }\end{array}$ & $\begin{array}{l}\text { Membiasakan anak mengurus } \\
\text { keperluanya sendiri }\end{array}$ & \\
\hline & & $\begin{array}{l}\text { keperluannya } \\
\text { sendiri }\end{array}$ & $\begin{array}{l}\text { Mengajarkan anak untuk } \\
\text { menabung }\end{array}$ & \\
\hline & & $\begin{array}{l}\text { Membiasakan } \\
\text { anak untuk }\end{array}$ & $\begin{array}{l}\text { Membiasakan anak melakukan } \\
\text { kegiatan sehari-hari pada waktunya }\end{array}$ & \\
\hline & & & $\begin{array}{l}\text { Memberikan contoh untuk bangun } \\
\text { pagi }\end{array}$ & \\
\hline \multirow[t]{5}{*}{ Jujur } & \multirow{5}{*}{$\begin{array}{l}\text { Cara-cara } \\
\text { yang } \\
\text { digunakan } \\
\text { orang tua agar } \\
\text { anak } \\
\text { mencapai } \\
\text { sesuatu } \\
\text { secara benar } \\
\text { dan berbicara } \\
\text { sesuai dengan } \\
\text { kenyataan }\end{array}$} & $\begin{array}{l}\text { Mengingatkan } \\
\text { agar anak }\end{array}$ & $\begin{array}{l}\text { Menasehati anak untuk tidak } \\
\text { mencontek }\end{array}$ & \multirow{5}{*}{$\begin{array}{l}\text { Manusia } \\
\text { semestinya hidup } \\
\text { saling percaya } \\
\text { sehingga harus } \\
\text { berusaha bertindak } \\
\text { dan berbicara } \\
\text { secara jujur. }\end{array}$} \\
\hline & & $\begin{array}{l}\text { mencapai } \\
\text { sesuatu } \\
\text { dengan benar }\end{array}$ & $\begin{array}{l}\text { Mengingatkan anak saat bermain } \\
\text { curang }\end{array}$ & \\
\hline & & $\begin{array}{l}\text { Membiasakan } \\
\text { anak untuk }\end{array}$ & $\begin{array}{l}\text { Menasehati anak untuk berbicara } \\
\text { sesuai kenyataan }\end{array}$ & \\
\hline & & $\begin{array}{l}\text { Dericara sesual } \\
\text { kenyataan }\end{array}$ & $\begin{array}{l}\text { Membiasakan anak berpamitan ke } \\
\text { mana akan pergi }\end{array}$ & \\
\hline & & & Memantau kegiatan anak & \\
\hline \multirow[t]{5}{*}{$\begin{array}{l}\text { Tresno } \\
\text { (cinta) }\end{array}$} & \multirow{5}{*}{$\begin{array}{l}\text { Cara-cara } \\
\text { yang } \\
\text { digunakan } \\
\text { orang tua agar } \\
\text { anak } \\
\text { memperoleh } \\
\text { rasa cinta dan } \\
\text { dukungan } \\
\text { dalam } \\
\text { menjalankan } \\
\text { kehidupannya } \\
\text { sehari-hari }\end{array}$} & \multirow{2}{*}{$\begin{array}{l}\text { Memberikan } \\
\text { dukungan } \\
\text { instrumetal }\end{array}$} & $\begin{array}{l}\text { Mengutamakan pemenuhan } \\
\text { kebutuhan anak }\end{array}$ & \multirow{5}{*}{$\begin{array}{l}\text { Manusia } \\
\text { semestinya dapat } \\
\text { saling } \\
\text { membahagiakan } \\
\text { sehingga } \\
\text { memberikan apa } \\
\text { yang dibutuhkan } \\
\text { orang lain menjadi } \\
\text { lebih penting } \\
\text { daripada } \\
\text { memenuhi } \\
\text { kebutuhan sendiri }\end{array}$} \\
\hline & & & $\begin{array}{l}\text { Membantu anak dalam } \\
\text { menghadapi kesulitan, terutama } \\
\text { masalah pelajaran sekolah }\end{array}$ & \\
\hline & & \multirow{3}{*}{$\begin{array}{l}\text { Memberikan } \\
\text { dukungan } \\
\text { emosional }\end{array}$} & Menunjukkan kasih sayang & \\
\hline & & & $\begin{array}{l}\text { Memberi perhatian pada apa yang } \\
\text { dirasakan anak }\end{array}$ & \\
\hline & & & Memberikan dorongan pada anak & \\
\hline
\end{tabular}




\section{Hasil Pengujian Model Pengukuran}

Dari proses expert judgment diperoleh beberapa masukan untuk perbaikan konstruk dan pernyataan-pernyataan. Berikut adalah tindak lanjut untuk penyusunan instrumen pengasuhan BNJ, yaitu (1) penamaan dan definisi aspek-aspek tetap sama; (2) terdapat tambahan penamaan indikator, yaitu indikator "mendorong kepekaan pada kebutuhan orang lain" pada aspek rukun; (3) memperbaiki rumusan pernyataan menjadi lebih konkret, pemilihan kata yang lebih tepat, dan penyusunan struktur kalimat; (4) pernyataanpernyataan yang dinilai memiliki maksud sama digunakan salah satu; dan (5) pernyataanpernyataan yang digunakan adalah pernyataan-pernyataan yang favorable saja agar lebih mudah dipahami oleh responden anak-anak. Selanjutnya, dilakukan pre-test dengan wawancara pada lima anak kelas $\mathrm{V}$ SD untuk memastikan bahwa pernyataanpernyataan dalam skala pengasuhan BNJ dapat dipahami dan sesuai dengan maksud pengukuran. Dari hasil tersebut diperoleh sebanyak 57 pernyataan yang telah diperbaiki dari hasil expert judgmet da pre-test yang akan dianalisis dalam uji model pengukuran.

Dari uji coba pertama $(n=334)$ diperoleh hasil bahwa sebagian besar pernyataan skala pengasuhan BNJ memiliki koefisien korelasi pernyataan-total $(R i x)$ di atas 0,25.
Selanjutnya, berdasarkan nilai muatan pernyataan dan fit model, tiap aspek dipilih sebanyak 35 pernyataan dengan empat hingga tujuh pernyataan untuk setiap aspek. Dengan ke-35 pernyataan, hasil CFA menunjukkan bahwa model pengukuran memenuhi GOF namun terdapat satu aspek yang memiliki nilai muatan di atas 1,0. Dari informasi Modification Indicies (MI) diketahui bahwa terdapat sejumlah pernyataan dan dua aspek, yaitu hormat dan rukun yang memiliki korelasi eror yang tinggi. Tindak lanjut atas informasi $M I$ ini adalah pernyataan-pernyataan diperbaiki, namun tetap mempertahankan aspek hormat dan rukun dan tidak dilakukan penggabungan nilai hormat dan rukun. Hal tersebut dilakukan dengan pertimbangan bahwa cara-cara pengasuhan untuk menanamkan kedua nilai ini memiliki penekanan yang berbeda. Nilai hormat lebih menekankan pemahaman anak mengenai posisi orang yang lebih tua sedangkan nilai rukun lebih menekankan pada pengendalian diri dalam berinteraksi dengan orang lain. Setelah sejumlah pernyataan diperbaiki dilakukan uji coba kedua dan hasil CFA terhadap data uji coba kedua $(\mathrm{N}=175)$ diperoleh hasil bahwa model pengukuran pengasuhan BNJ telah fit seperti yang ditunjukkan Gambar 1.

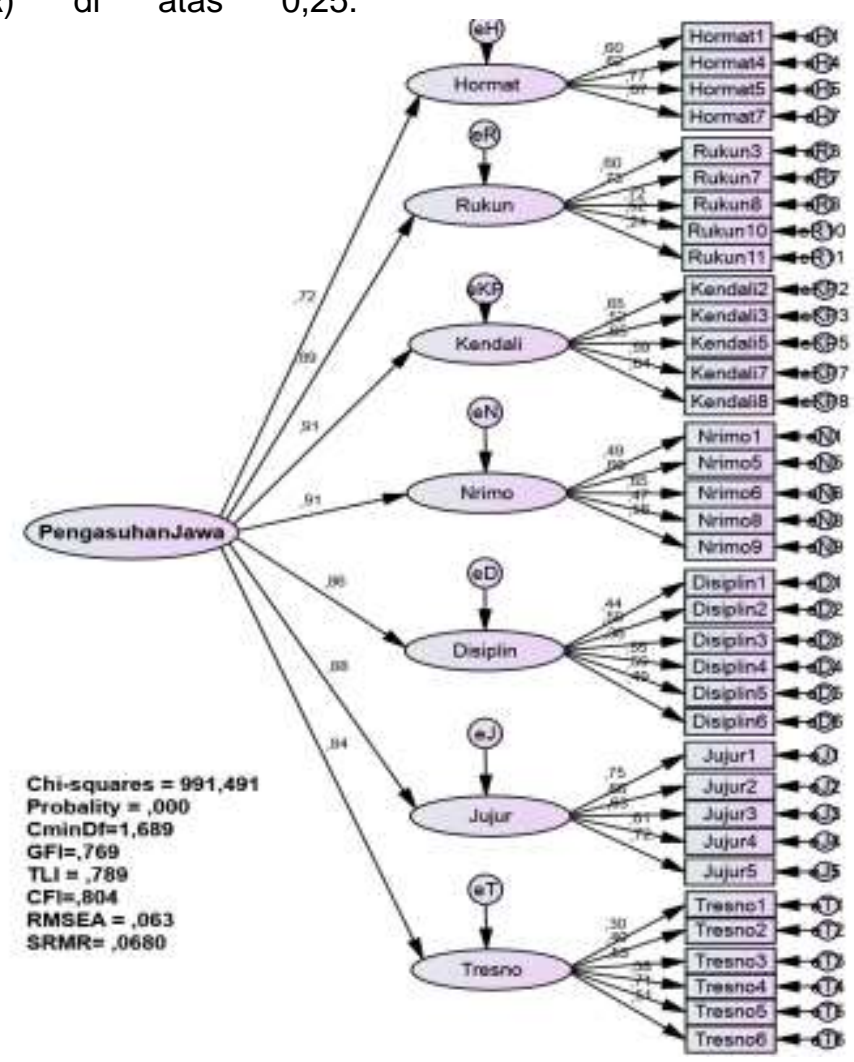

Gambar 1 Model pengukuran pengasuhan BNJ 
Tabel 2 Indikator Goodness of Fit Model pengukuran pengasuhan BNJ

\begin{tabular}{lccc}
\hline \multicolumn{1}{c}{ Indikator } & Hasil & Kriteria & Kesimpulan \\
\hline $\begin{array}{l}\text { Chi- } \\
\text { square }\end{array}$ & 991,491 & $\begin{array}{c}\text { Seminimal } \\
\text { mungkin }\end{array}$ & \\
Probability & 0,000 & $\geq 0,05$ & \\
CminDf & 1,689 & $\leq 2,00$ & Fit \\
GFI/ TLI/ & $0,769 /$ & $\geq 0,90$ & \\
CFI & $0,789 /$ & & \\
& 0,804 & & \\
RMSEA & 0,063 & $\leq 0,08$ & Fit \\
SRMR & 0,068 & $\leq 0,08$ & Fit \\
\hline
\end{tabular}

Selanjutnya, Tabel 2 menunjukkan bahwa terdapat tiga indikator Goodness of Fit (GOF) yang memenuhi kriteria, yaitu CminDf (lebih kecil dari 2,0) serta RMSEA dan SRMR (lebih kecil dari 0,08). Oleh karenanya, dapat disimpulkan bahwa model pengukuran pengasuhan BNJ telah fit atau sesuai dengan data di lapangan.

Selanjutnya Tabel 3 menunjukkan bahwa ketujuh aspek pengasuhan memiliki muatan faktor di atas 0,7. Artinya, ketujuh aspek memiliki sumbangan yang ideal untuk menjelaskan konstruk pengasuhan BNJ. Pernyataan-pernyataan dalam model pengukuran Pengasuhan BNJ yaitu sebanyak 36 pernyataan juga memiliki muatan faktor yang baik, yaitu berkisar antara 0,3 sampai 0,85 . Artinya, pernyataan-pernyataan ini dapat mencerminkan aspek-aspeknya. Koefisien Cronbach's alpha skala pengasuhan BNJ dengan 36 pernyataan ini adalah 0,925. Dengan demikian, skala pengasuhan BNJ dalam penelitian ini memiliki validitas dan reliabilitas yang baik.

Tabel 3 Muatan faktor aspek-aspek pengasuhan berbasis nilai Jawa (BNJ)

\begin{tabular}{|c|c|c|c|}
\hline Aspek Nilai & $\begin{array}{r}\text { Pernyataan } \\
\end{array}$ & Muatan Faktor & Muatan Faktor \\
\hline & Pembiasaan memberi salam & $0,60^{\star *}$ & $0,72^{\star \star}$ \\
\hline \multirow[t]{3}{*}{ Hormat } & Pembiasaan ucapan permisi & $0,62^{\star \star}$ & \\
\hline & Mengajarkan tingkatan bahasa Jawa & $0,77^{\star \star}$ & \\
\hline & Membetulkan cara bicara & $0,67^{\star *}$ & \\
\hline \multirow[t]{7}{*}{ Rukun } & Berbicara tenang saat jengkel & $0,60^{* *}$ & $0,89^{\star *}$ \\
\hline & Contoh membantu tetangga & $0,73^{\star *}$ & \\
\hline & Mengajarkan melayani tamu & $0,72^{\star *}$ & \\
\hline & Melibatkan anak dalam kerja bakti & $0,52^{\star *}$ & \\
\hline & Melibatkan anak dalam perayaan & $0,24^{\star \star}$ & \\
\hline & Pembiasaan cara duduk & $0,65^{\star *}$ & $0,91^{* *}$ \\
\hline & Ajaran "ilok-ora ilok" saat makan & $0,52^{\star *}$ & \\
\hline \multirow[t]{5}{*}{ Kendali Perilaku } & Menasehati agar tidak membuat malu & $0,65^{\star \star}$ & \\
\hline & Teguran pada bicara yang keras & $0,59^{\star \star}$ & \\
\hline & Teguran terhadap gerakan kasar & $0,64^{\star \star}$ & \\
\hline & Memberi pengertian & $0,49^{\star *}$ & $0,91^{* *}$ \\
\hline & Makan apa yang tersedia & $0,60^{* *}$ & \\
\hline \multirow[t]{5}{*}{ Nrimo } & Contoh untuk bersyukur & $0,65^{\star *}$ & \\
\hline & Memberikan dorongan saat gagal & $0,47^{\star \star}$ & \\
\hline & Menciptakan suasana gembira & $0,56^{\star *}$ & \\
\hline & Memberi tugas rumah tangga & $0,44^{\star *}$ & $0,86^{\star *}$ \\
\hline & Melibatkan menjaga kebersihan rumah & $0,59^{\star \star}$ & \\
\hline \multirow{6}{*}{ Disiplin } & Memuji jika anak belajar & $0,36^{\star *}$ & \\
\hline & Pembiasaan kegiatan pada waktunya & $0,55^{\star \star}$ & \\
\hline & Memberi contoh bangun pagi & $0,59^{* *}$ & \\
\hline & Membatasi waktu bermain & $0,49^{\star *}$ & \\
\hline & Nasehat tidak mencontek & $0,75^{\star \star}$ & $0,88^{* *}$ \\
\hline & Pembiasaan meminta ijin mengambil & $0,66^{\star *}$ & \\
\hline \multirow[t]{5}{*}{ Jujur } & Mengingatkan agar tidak curang & $0,63^{\star *}$ & \\
\hline & Memberi contoh berkata jujur & $0,61^{\star *}$ & \\
\hline & Pembiasaan untuk pamit & $0,72^{\star \star}$ & \\
\hline & Menemani belajar & $0,30^{\star *}$ & \\
\hline & Memenuhi kebutuhan & $0,40^{\star *}$ & $0,84^{\star *}$ \\
\hline \multirow{4}{*}{ Tresno } & Menyediakan bantuan & $0,53^{\star *}$ & \\
\hline & Dorongan untuk bersemangat & $0,58^{* *}$ & \\
\hline & Menenangkan anak saat cemas & $0,71^{\star *}$ & \\
\hline & Memberi perhatian saat anak murung & $0,51^{* *}$ & \\
\hline
\end{tabular}

'Keterangan: 'signifikan; "sangat signifikan 


\section{PEMBAHASAN}

Studi ini dilakukan untuk mengembangkan instrumen pengukuran atau skala pengasuhan berbasis nilai Jawa (pengasuhan BNJ). Pengembangan instrumen pengasuhan dalam penelitian ini bertitik tolak dari konsep pengasuhan dari Darling dan Steinberg (1993). Konsep ini memuat tujuan pengasuhan sebagai elemen dasar dalam pengasuhan sehingga memungkinkan konstruk pengasuhan dapat dikembangkan secara kontektual sesuai dengan budaya setempat.

Berdasarkan pendekatan kontekstual, pengembangan instrumen dilakukan secara induktif, yaitu diawali dengan eksplorasi konstruk pengasuhan. Dari tahap eksplorasi diperoleh konstruk pengasuhan BNJ, yaitu pengasuhan yang dilandasi tujuh aspek nilai budaya Jawa. Ketujuh nilai tersebut meliputi nilai hormat, rukun, kendali perilaku, "nrimo" (sikap menerima), disiplin, jujur, dan "tresno" (cinta). Hasil pengujian model pengukuran menunjukkan bahwa ketujuh nilai memiliki muatan yang cukup besar (di atas 0,7) dan bersama-sama membangun konstruk pengasuhan berbasis nilai Jawa (BNJ). Skala yang dikembangkan dari konstruk ini dapat dinyatakan valid dan reliabel.

Sebagian besar nilai yang melandasi pengasuhan keluarga Jawa saat ini, yakni nilai hormat, rukun, kendali perilaku, "nrimo" (sikap menerima), disiplin, jujur, dan "tresno" (cinta); merupakan nilai-nilai yang telah dikenal dalam budaya Jawa dan masih diartikan dalam makna yang sama. Oleh karenanya, dapat disimpulkan bahwa pengasuhan dalam keluarga Jawa saat ini masih mengedepankan nilai-nilai budaya Jawa yang telah dikenal dari generasi sebelumnya. Nilai-nilai akan tetap dipertahankan dari generasi ke generasi selama nilai-nilai ini dianggap baik bagi kesejahteraan manusia. Nilai adalah sentral dari pikiran dan perilaku manusia, dan ketika nilai-nilai tersebut dianggap sangat penting bagi seseorang maka nilai akan dipertahankan (Maio \& Olson, 1998).

Dilihat dari istilah atau penamaannya, nilai-nilai yang melandasi pengasuhan Jawa, seperti nilai disiplin, jujur dan cinta merupakan nilai yang universal. Nilai hormat dan kerukunan merupakan nilai-nilai yang umum di budayabudaya Asia (Huang \& Gove, 2015; Zhang, Lin, Nonaka, \& Beom, 2005). Namun, sebagian besar nilai-nilai dalam pengasuhan $\mathrm{BNJ}$ ini memiliki falsafah dan makna yang khas dalam budaya Jawa dan akan dibahas berikut ini.

Nilai hormat merupakan salah satu nilai yang cukup umum menandai budaya kolektivis (Zhang et al., 2005). Namun demikian, penelitian ini maupun penelitian sebelumnya (Wardani \& Uyun, 2017) menemukan bahwa dibandingkan budaya lain, masyarakat Jawa menempatkan nilai hormat ini sebagai nilai yang utama dalam kehidupan bermasyarakat sehari-hari. Dalam tahap eksplorasi, cara-cara pengasuhan yang dilandasi nilai hormat adalah hal yang pertama dan paling banyak disebutkan. Praktik pengasuhan dengan nilai hormat antara lain dicerminkan dengan sosialisasi pada anak tentang kedudukan dirinya dan kedudukan orang lain yang dihadapinya. Anak selalu diingatkan untuk menunjukkan rasa hormat pada orang yang lebih tua dan tidak bersikap seenaknya dengan orang tua. Oleh karena itu, makna dari aspek hormat masih relatif sama dengan apa yang ditemukan dalam literatur terdahulu. Nilai hormat bagi keluarga Jawa berhubungan dengan prinsip hierarki dalam relasi sosial, dalam hal ini orang yang lebih tua memiliki kedudukan yang lebih tinggi (Geertz, 1983; Suseno, 1984).

Selanjutnya, pada nilai rukun, hasil eksplorasi dalam penelitian ini menunjukkan bahwa nilai rukun masih menjadi salah satu nilai yang diutamakan dalam budaya Jawa dan memiliki makna yang sama dengan yang disampaikan di literatur terdahulu. Praktik nilai rukun dalam pengasuhan meliputi dorongan orang tua agar anak mau bersabar atau mengalah pada orang lain, untuk tanggap dan peduli terhadap keadaan orang lain, serta melibatkan anak dalam kegiatan bersama masyarakat sekitar. Praktik pengasuhan ini ditujukan agar anak mampu menghindari konflik dengan orang lain dan memiliki relasi yang selaras dengan masyarakat di sekitarnya. Seperti nilai hormat, nilai rukun atau harmoni merupakan nilai yang umum dalam budaya kolektivis (Zhang et al., 2005). Karakteristik nilai rukun dalam budaya Jawa terletak pada cara menjaga harmoni tersebut, yakni dengan mengendalikan ungkapan emosi, cenderung menyimpan masalah-masalah untuk diri sendiri, dan tidak mengganggu ketentraman orang lain (Geertz, 1983; Suseno, 1984).

Nilai pengasuhan BNJ yang ke-tiga adalah kendali perilaku. Orang tua saat ini memandang bahwa pengendalian perilaku merupakan nilai yang khas dan masih penting dimiliki oleh anak-anak dalam keluarga Jawa. 
Nilai kendali perilaku dipraktikkan orang tua dengan memberitahu mana perilaku yang pantas (ilok) atau tidak (ora ilok) misalnya dalam hal duduk, makan dan berpakaian. Nilai kendali juga tampak dari pembiasaan anak untuk berperilaku secara halus misalnya dalam berbicara, meletakkan barang-barang, atau menutup pintu. Praktik pengasuhan yang dilandasi nilai kendali perilaku ditujukan agar anak memiliki pembawaan diri yang halus dan memiliki kepekaan di dalam dirinya sehingga perilakunya tidak mengganggu ketenangan di lingkungannya. Nilai kendali diri tidak berhubungan secara langsung dengan relasi sosial tetapi lebih pada cara orang Jawa membawa diri atau menampilkan dirinya. Literatur yang lebih baru juga menyebutkan bahwa orang Jawa dikenal memiliki pembawaan yang halus, baik dalam berbicara maupun tingkah laku sehari-hari (Karomani, 2011).

Hasil eksplorasi dalam penelitian ini untuk nilai ke-empat yaitu "nrimo" menemukan bahwa orang tua berusaha menanamkan sikap "nrimo" dalam pengasuhannya. Praktik pengasuhan yang dilandasi sikap "nrimo" dalam keluarga Jawa dilandasi oleh pandangan bahwa manusia semestinya dapat mengendalikan keinginan-keinginan pribadinya sehingga selalu bersikap menerima dan tetap menjalani kehidupan dalam keadaan apapun. "Nrimo" adalah salah satu sikap "sepi ing pamrih" (tidak mengejar kepentingan sendiri), tidak melakukan protes terhadap apa yang dimiliki, dan tetap tekun menjalani kehidupan (Mulder, 1983; Suseno, 1984). Sikap "nrimo" merupakan nilai yang khas dalam budaya Jawa. Sebuah penelitian (Yuniarti, 2006) menemukan bahwa "nrimo" berhubungan dengan keyakinan bahwa bencana merupakan sesuatu yang telah ditentukan Tuhan dan memberikan energi positif yang dapat membuat penyintas lebih cepat untuk bangkit kembali.

Nilai disiplin yang merupakan nilai ke-lima dalam pengasuhan BNJ yang dimaksudkan orang tua dalam $F G D$ relevan dengan nilai kerja keras ("rame ing gawe") yang disebutkan dalam literatur terdahulu (Suseno, 1984), meskipun tidak sama persis. Nilai disiplin tidak sebatas memuat kerja keras yang dimaksudkan untuk melaksanakan apa yang telah menjadi tugas anak tetapi juga dimaksudkan agar anak-anak melakukan apa yang baik untuk dilakukan, seperti dalam penggunaan waktu dan uang (menabung). Adanya nilai disiplin yang melandasi pengasuhan menunjukkan adanya penyesuaian keluarga-keluarga Jawa terhadap tuntutan jaman saat ini. Dalam FGD muncul kekhawatiran bahwa anak-anak saat ini kurang mendapatkan pendampingan dan pengawasan terhadap anak akibat tuntutan pekerjaan dan kesibukan orang tua. Oleh karena itu, orang tua menginginkan agar anak lebih memiliki rasa tanggung jawab, dapat menilai mana hal yang baik, dan mengarahkan dirinya sendiri dalam menggunakan waktu dan menjalankan kegiatannya sehari-hari. Dari penjelasan orang tua dan pandangan yang mendasari pentingnya nilai disiplin tampak bahwa nilai disiplin ini merupakan nilai yang universal namun dipandang penting untuk dipraktikkan dalam keluarga-keluarga Jawa saat ini.

Nilai yang ke-enam adalah jujur dan hasil penelitian menunjukkan bahwa pandangan orang tua Jawa saat ini mengenai nilai jujur berbeda dengan pandangan filosofi mengenai nilai jujur di kalangan orang Jawa terdahulu. Pandangan terdahulu mengenai nilai jujur adalah bahwa manusia harus dapat dipercaya dengan menepati janji dan memiliki kesungguhan dalam menjalankan apa yang telah menjadi tugasnya atau dalam istilah Jawa adalah "temen" (Suseno, 1984). Pandangan orang tua Jawa saat ini tentang nilai jujur lebih berkaitan dengan cara mendapatkan sesuatu dengan benar dan kesesuaian perkataan dengan kenyataan. Pandangan tersebut menunjukkan bahwa saat ini nilai jujur dimaknai lebih universal yaitu menyangkut kebenaran (Lestari, 2013; Wang \& Leung, 2010). Bagi orang tua Jawa saat ini, nilai kejujuran menjadi nilai yang mutlak dimiliki oleh anak-anak. Pengasuhan dengan nilai jujur dilakukan orang tua dengan menasehati anak untuk tidak berbuat curang dan membiasakan anak untuk mengatakan hal-hal sesuai dengan kenyataan.

Selanjutnya, berdasarkan hasil $F G D$ terkait nilai ke-tujuh yaitu "tresno" (cinta) menunjukkan bahwa ungkapan cinta ditunjukkan orang tua untuk memberikan teladan mengenai tindakan kasih sayang dan agar tercipta iklim saling pengertian dalam relasi orang tua-anak. Pengasuhan yang dilandasi oleh nilai cinta antara lain dilakukan dengan berusaha memenuhi kebutuhan anak dan mempertimbangkan apa yang dirasakan oleh anak. Dalam pengasuhan Jawa terdahulu, ibu merupakan tempat anak-anak dapat mengungkapkan apapun yang dirasakan dan memperoleh pemenuhan kebutuhan baik fisik maupun psikologis (Geertz, 1983). Para peneliti juga menemukan bahwa ungkapan cinta dari orang tua menumbuhkan rasa 
percaya (trust) anak pada orang tua (Hakim, Thontowi, Yuniarti, \& Kim, 2012). Nilai cinta ini merupakan nilai yang universal dan serupa dengan apa yang disebut para ahli sebagai kehangatan atau warmth (Baumrind, 1966; Skinner, Johnson \& Snyder, 2005).

Berdasarkan uraian tersebut, sebagian besar nilai-nilai yang melandasi pengasuhan BNJ adalah nilai-nilai yang khas dalam budaya Jawa. Nilai hormat dan rukun, dua nilai yang utama dalam pengasuhan BNJ, merupakan nilai-nilai budaya kolektif yang mengedepankan harmoni sosial dalam kehidupan manusia, namun dalam budaya Jawa memiliki kekhasan dalam praktik (cara) pengasuhannya. Dua nilai yaitu nilai kendali perilaku dan "nrimo" merupakan nilai yang khas dalam budaya Jawa, yang dilandasi oleh falsafah mengenai pentingnya pengendalian diri dan keinginan-keinginan pribadi untuk mempertahankan ketentraman lingkungan. Tiga nilai yaitu nilai disiplin, jujur dan tresno (cinta) merupakan nilai-nilai yang lebih umum atau universal. Nilai-nilai yang melandasi pengasuhan dalam keluarga Jawa saat ini masih memiliki banyak kesamaan makna dengan nilai-nilai yang dijelaskan dalam literatur terdahulu. Budaya adalah perilaku dan makna yang dipelajari bersama yang diperoleh dalam konteks aktivitas kehidupan dan diwariskan dari generasi ke generasi untuk tujuan meningkatkan kelangsungan hidup dan adaptasi manusia (Marsella, 2010). Oleh karena itu walaupun budaya dapat berubah sejalan dengan perkembangan jaman, namun budaya dalam bentuk nilai-nilai yang mejamin kesejahteraan manusia akan tetap dipertahankan.

Dibandingkan dengan instrumen pengasuhan pada umumnya, instrumen BNJ yang dikembangkan dalam penelitian ini memiliki beberapa kekhususan. Pertama, instrumen pengasuhan ini tidak hanya menghasilkan gambaran mengenai pola atau gaya pengasuhan (seperti pada PSDQ dan PCRQ) namun juga tujuan yang hendak dicapai dalam pengasuhan. Kedua, instrumen pengasuhan ini dapat menghasilkan gambaran pengasuhan yang bersifat indigenenus yaitu gambaran pengasuhan di Indonesia khususnya dalam keluarga-keluarga Jawa.

Dari seluruh definisi dan falsafah yang melandasi nilai-nilai tersebut maka pengasuhan dalam budaya Jawa mencerminkan empat sikap orang tua kepada anak, yakni mendorong anak untuk harmoni dengan lingkungannya, memiliki pengendalian diri dan rasa tanggung jawab, sekaligus memberikan dukungan kepada anak. Jika iklim pengasuhan di barat ditandai dengan dorongan untuk berinisiatif dan otonom (Keller \& McDade, 2000; Wise \& da Sylva, 2007) maka pengasuhan dalam keluarga Jawa ditandai dengan dorongan untuk selaras atau harmoni dengan orang lain dan memiliki rasa tanggung jawab.

Konstruk pengasuhan yang berbasis pada nilai-nilai budaya Jawa menghasilkan model pengukuran yang fit. Hasil ini menunjukkan bahwa pengasuhan merupakan konsep yang kontekstual dan muatan dalam pengasuhan tidak dapat lepas dari budaya setempat. Berdasarkan pada teori ekologi, salah satu teori dalam perspektif kontekstual, pengasuhan dapat mewakili microsystem atau lingkungan terdekat anak. Karakteristik microsystem dipengaruhi oleh macrosystem atau nilai-nilai yang berlaku di masyarakat atau budaya setempat (Bronfenbrenner, 1986).

\section{SIMPULAN DAN SARAN}

Model instrumen pengasuhan berbasis nilai Jawa (BNJ) telah sesuai (fit). Hasil ini menunjukkan bahwa pengasuhan merupakan konsep yang kontekstual. Konstruk pengasuhan dalam perspektif kontekstual adalah konstuk pengasuhan yang berbasis pada tujuan pengasuhan, yang dalam hal ini meliputi nilai-nilai budaya setempat. Pengasuhan BNJ adalah sejumlah tindakan yang dilakukan orang tua untuk mengembangkan kemampuan anak dalam menjalin hubungan yang selaras dengan orang lain dan menjalani kehidupannya sehari-hari dengan dilandasi nilai-nilai budaya Jawa. Nilainilai budaya yang melandasi pengasuhan dalam keluarga-keluarga Jawa saat ini meliputi nilai hormat, rukun, pengendalian perilaku, nrimo, disiplin, jujur dan tresno (rasa cinta). Dengan mempertimbangkan hasil penelitian ini maka disarankan bagi penelitian-penelitian selanjutnya untuk menggunakan pengukuran pengasuhan yang berbasis pada budaya setempat.

\section{DAFTAR PUSTAKA}

[BPS] Badan Pusat Statistik. (2011). Kewarganegaraan, Suku Bangsa, Agama dan Bahasa Sehari-hari Penduduk Indonesia Hasil Sensus Penduduk 2010.

Ainsworth, M. D. S., \& Bowlby, J. (1991). An ethological approach to personality development. American Psychologist, 
46(4), 333-341. doi10.1037/0003066x.46.4.333.

Ang, R. P., \& Goh, D. H. (2006). Authoritarian parenting style in asian societies: a cluster- analytic investigation. Contemporary Family Therapy, 28(1), 131-151. doi:10.1007/s10591-006-9699.

Aunola, K., Stattin, H., \& Nurmi, J. E. (2000). Adolescents' achievement strategies, school adjustment, and externalizing and internalizing problem behaviors. Journal of Youth and Adolescence, 29(3), 289306. doi:10.1023/a:1005143607919

Baumrind, D. (1966). Effects of authoritative parental control on child behavior. Child development, 37(4), 887-907. Retreived from http://www.jstor.org/stable/1126611.

Bibi, F., Chaudhry, A. G., Awan, E. A., \& Tariq, B. (2013). Contribution of parenting style in life domain of children. IOSR Journal of humanities and social science (IOSRJHSS), 12(2), 91-95. Diunduh dari http://www.iosrjournals.org/iosrjhss/papers/Vol12-issue2/M01229195.pdf

Braun, V., \& Clarke, V. (2006). Using thematic analysis in psychology. Qualitative Research in Psychology, 3, 77-101. doi:10.1191/1478088706qp063oa.

Bronfenbrenner, U. (1986). Ecology of the family as a context for human development: Research perspectives. Developmental Psychology, 22(6), 723742. doi:10.1037/0012-1649.22.6.723

Chao, R. K. (2000). The parenting of immigrant Cchinese and Eeuropian Aamerican mothers: relations between parenting styles, socialization, and parental practices. Journal of Applied Developmental Psychology, 21(2). 233248. doi:10.1016/S0193-3973(99)000374.

Chao, R.K. (1994). Beyond parental control and authoritarian parenting style: understanding Cchinese parenting through the cultural notion of training. Child Development, 65(4), 1111-1119. doi:10.2307/1131308.

Clarke-Stewart, A. (2006). What have we learned: Proof that families matter, policies for families and children, prospects for future research. In ClarkeStewart, A., \& Dunn, J. (Eds). Families Count (pp.321-336). London: Cambridge University Press.
Creswell, J. W. (2014). A concise introduction to mixed methods research. SAGE publications.

Darling, N., \& Steinberg, L. (1993). Parenting style as context: An integrative model. Psychological Bulletin, 113(3), 487-496. doi:10.1037/0033-2909.113.3.487.

Deater-Deckard, K., \& Dodge, K. A. (1997). Externalizing Behavior Problems and Discipline Revisited: Nonlinear Effects and Variation by Culture, Context, and Gender. Psychological Inquiry, 8(3), 161175. doi:10.1207/s15327965pli0803_1

Field, A. (2009). Discovering Statistics Using SPSS. (3rd ed). London: Sage.

Geertz, H. (1983). Keluarga Jawa. Jakarta (ID): Grafiti Press.

Grusec, J. E. (2002). Parental socialization and children's acquisition of values. Dalam Bornstein, M.H (ed). Handbook of Parenting, Vol. 5 Practical Issues in Parenting (2nd ed). New Jersey: Lawrence Erlbaum Associates, Inc.

Hakim, M., Thontowi, H., Yuniarti, K., \& Kim, U. (2012). The basis of children's trust towards their parents in Java, ngemong: ilndigenous psychological analysis. International Journal of Research Studies in Psychology, 1 (2), 3-16. doi: 10.5861/ijrsp.2012.v1i2.78.

Hinkin, T. R., Tracey, J. B., \& Enz, C. A. (1997). Scale construction: developing reliable and valid measurement instruments. Journal of Hospitality \& Tourism Research, 21(1), 100-120. doi:10.1177/109634809702100108.

Hu, L. T., \& Bentler, P. M. (1999). Cut off criteria for fit indexes in covariance structure analysis: Conventional criteria versus new alternatives. Structural Equation Modeling, 6(1), 1-55. doi:10.1080/10705519909540118.

Huang, G. H., \& Gove, M. (2015). Asian parenting styles and academic achievement: views from eastern and western perspectives. Education, 135 (3), 389-397.

Idrus, M. (2005). Kepercayaan eksistensial remaja Jawa. Jurnal Psikologi Islam, 1 (1), 73-86. Rerieved from http://jpi.apihimpsi.org/index.php/jpi/article/view/19

Karomani. (2011). Persepsi dan prasangka antaretnik di Lampung Selatan: studi komunikasi antaretnik Di Bakauheni Kalianda. Sosiohumaniora, 13(1), 39-57. 
doi:10.24198/sosiohumaniora. v13i1.5461.

Keller, J., \& McDade, K. (2000). Attitudes of low-income parents toward seeking help with parenting: Implications for practice. Child welfare, 79, 285-312.

Kim, J. M. S. (2006). Korean parents' disciplinary practices and socioeconomic status: An investigation based on disciplinary domains and language functions. (Disertasi) Greensboro: Faculty of The Graduate School at The University of North Carolina. Diunduh dari https://libres.uncg.edu/ir/uncg/f/umi-uncg1165.pdf.

Kim, S. Y., \& Wong, V. Y. (2002). Assessing Asian and Asian American Parenting: a review of the literature. Asian American Mental Health, 185-201. doi:10.1007/9781-4615-0735-2_13

Lestari, S. (2013). Konsep dan transmisi nilainilai jujur, rukun dan hormat. (Disertasi). Yogyakarta: Universitas Gadjah Mada, Yogyakarta, Indonesia.

Maccoby, E. E. (1992). The role of parents in the socialization of children: An historical overview. Developmental Psychology, 28(6), 1006-1017. Doi: 10.1037/00121649.28.6.1006.

Maccoby, E. E., \& Martin, J. A. (1983). Socialization in the Context of the Family: Parent-child Interaction. Dalam E. Hetherington (ed). Handbook of Child Psychology, 4. New York: Wiley.

Maio, G. R., \& Olson, J. M. (1998). Values as truisms: evidence and implications. Journal of Personality and Social Psychology, 74, 294-311. doi: 10.1037/0022-3514.74.2.294.

Mulder, N. (1983). Kebatinan dan Hidup Sehari-hari Orang Jawa. Kelangsungan dan Perubahan Kulturil. Jakarta : Percetakan PT Gramedia.

Nguyen, N. A., \& Williams, H. L. (1989). Transition from east to west: Vietnamese adolescents and their parents. Journal of the American Academy of Child and Adolescent Psychiatry, 28, 505-515. doi: 10.1097/00004583-198907000-00007

Phinney, J. S., Ong, A., \& Madden, T. (2000). Cultural values and intergenerational value discrepancies in immigrant and nonimmigrant families. Child Development, 71(2), 528-539. Diunduh dari :http://www.jstor.org/stable/1132007
Power, T. G. (2013). Parenting Dimensions and Styles: A Brief History and Recommendations for Future Research. Childhood Obesity, 9(s1), S-14-S-21. doi:10.1089/chi.2013.0034

Quoss, B., \& Zhao, W. (1995). Parenting styles and children's satisfaction with parenting in China and the United States. Journal of Comparative Family Studies. 26 (2), 265280. Diunduh dari http://www.jstor.org/stable/41602383.

Randolph, S. M. (1995). African American children in single-mother faniilies. Dalam B. J. Dickerson (Ed.), African American single mothers: Understanding their lives and families (Vol. 10, pp. 117-145). Thousand Oaks, CA: Sage.

Rohner, R. P. (2004). The parental "Acceptance-Rejection Syndrome": universal correlates of perceived rejection. American Psychologist, 59(8), 830-840. doi:10.1037/0003-066x. 59.8.830

Rohner, R. P., \& Rohner, E.C. (1981). Education parental acceptance-rejection and parental control: cross-cultural codes. Ethnology, 20(3), 245-260, doi: $10.2307 / 3773230$.

Shucksmith, J., Hendry, L. B., \& Glendinning, A. (1995). Models of parenting: implications for adolescent well-being within different types of family contexts. Journal of Adolescence, 18(3), 253-270. doi:10.1006/jado.1995.1018

Skinner, E., Johnson, S., \& Snyder, T. (2005b). Six dimensions of parenting: a motivational model. Parenting, 5(2), 175235. doi:10.1207/s15327922par0502_3.

Steinberg, L., Lamborn, S. D., Darling, N., Mounts, N. S., \& Dornbusch, S.M. (1994). Over-tTime changes in adjustment and competence among adolescents from authoritative, authoritarian, indulgent, and neglectful families. Child Development, 65(3) 754-770. doi:10.1111/j.14678624. 1994.tb00781.x.

Subramony, D. P., Lindsay, N., Middlebrook, R. H., \& Fosse, C. (2002). Using focus group interviews. Performance Improvement, 41(8), 40-47. doi:10.1002/pfi.4140410810.

Suseno, F. M. (1984). Etika Jawa: Sebuah Analisa Falsafi Tentang Kebijaksanaan Hidup Orang Jawa. Jakarta (ID): Gramedia Pustaka Utama. 
Talib, J., Mohamad, Z., \& Mamat, M. (2011). Effects of parenting style on children development. World Journal of Social Sciences, 1(2), 14-35. Diunduh dari https://pdfs.semanticscholar.org/4d1b/ d5803fd42f4e15001b5ba2ae1a1b5215cf0 5.pdf

Wang, C. S., \& Leung, A. K. (2010). The cultural dynamics of rewarding honesty and punishing deception. Personality and Social Psychology Bulletin, 36(11), 15291542., doi:10.1177/0146167210385921.

Wardani, F. L. R. \& Uyun, Z. (2017) "Ngajeni wong liyo"; menghormati orang yang lebih tua pada remaja etnis Jawa. Indigenous: Jurnal Ilmiah Psikologi, 2 (2), 176-183. Diunduh dari: http://journals.ums.ac.id/index.php/indigen ous/article/download/5681/3793

Wise, S., \& da Silva, L. (2007). Differential parenting of children from diverse cultural backgrounds attending child care. Research Paper, 39. Diunduh dari https://aifs.gov.au/sites/default/files/public ation-documents/rp39.pdf.
Wyer, R. S., Chiu, C., \& Hong, Y. (2009) Understanding culture. Theory, research, and application. New York: Taylor \& Francis Group.

Xu, C. (2007). Direct and indirect effects of parenting style with child temperament, parent-child relationship, and family functioning on child social competence in the Chinese culture: Testing The latent models. (Disertasi). University Of North Texas, Texas, US

Yuniarti, K. W. (2006). The magical strength of nrimo and gotong-royong a quick response report following the May 27, 2006 earthquake in Yogyakarta. Anima Jurnal Psikologi Anime Journal of Psychology, 24(3), 201-206. Diunduh dari http://www.anima.ubaya.ac.id/class/ openpdf. php?file $=1371801925$. pdf

Zhang, Y. B., Lin, M. C., Nonaka, A., \& Beom, K. (2005). Harmony, hierarchy and conservatism: a cross-cultural comparison of confucian values in China, Korea, Japan, and Taiwan. Communication Research Reports, 22(2), 107-115, doi:10.1080/00036810500130539. 